\title{
Concept of Criminal Law on Corruption of Corporate Criminal Liability System Based on Justice Value
}

\author{
Abdul Kholiq Nur ${ }^{*}$ and Gunarto ${ }^{* *}$ \\ *) Student of Master of Law, Faculty of Law, Universitas Islam Sultan Agung Semarang, \\ E-mail: abdulkholiqnur@gmail.com \\ ${ }^{* *}$ ) Faculty of Law, Universitas Islam Sultan Agung Semarang
}

\begin{abstract}
The purpose of writing is to analyze the corporate accountability system in order to impose crimes against corporations, and obstacles to imposing crimes against corporations. The method used is the statute approach and the case approach, the analysis method uses qualitative analysis with interpretation, and the data collection method uses library research. It can be concluded that corporations can be held accountable by using a system of absolute and substitute liability, and the obstacle is the application of a conventional criminal liability system and the difficulty of proving corporate wrongdoing. It is suggested that there is a common perception among law enforcers about the criminality of corporations.

Keywords: Corporation; Justice Value; Criminal Liability.
\end{abstract}

\section{Introduction}

The current Criminal Code (KUHP) is a legacy from the Dutch Government, which has been in effect since 1918. After Indonesia's independence in 1945 based on Article II of the Transitional Rules of the 1945 Constitution, the Criminal Code is declared to remain valid throughout Indonesia to fill in legal vacuum (rechts vacuum), and adjusted to the condition of Indonesia after independence by Act No. 1 of 1946 in conjunction with Act No. 73 of 1958.

The Criminal Code is often lagging behind the development of crime that happens in society so that it must be patched up to keep up with these developments. As a result, a law was born that changed and added to the Criminal Code. Even so, the Criminal Code is still lagging behind the development of crime. Therefore, in addition to laws that partially amend and add to the Criminal Code, criminal law laws are also made that are spread outside the Criminal Code or which are called special criminal laws such as Act No. 31 of 1999 concerning Eradication. Corruption Crime (hereinafter referred to as UUPTPK), in conjunction with Act No. 20 of 2001 concerning Amendments to Act No. 31 of 1999 concerning Eradication of Corruption Crimes.

Forming a special criminal law must meet certain criteria as proposed by Loebby Loqman. Special crimes must meet certain criteria as suggested by Loebby Loqman ${ }^{1}$, that an act must be regulated separately in a special criminal law because:

- If it is entered into the codification (KUHP) it will damage the codification system;

- Due to certain circumstances such as emergencies; and

- Due to the difficulty of making changes or additions to the codification, because in certain cases deviation from the existing system is desired.

\footnotetext{
${ }^{1}$ Loqman, Loebby. (1993). Delik Politik Di Indonesia. IND-HILL-CO. p. 111
} 
From the above criteria, it is connected with Act No. 311999 in conjunction with Act No. 20 of 2001, it is known that there are special matters in this law that are different from the Criminal Code. Among them are corporate problems as subjects of criminal law, where corporations can commit criminal acts and can be held accountable. So the UUPTPK cannot be included in the KUHP because the special things regulated in the UUPTPK will change the KUHP system.

Indonesian criminal law has recognized corporations as legal subjects since the existence of Emergency Act No. 17 Of 1951 concerning Stockpiling of Goods, and Act No. 7 Emergency Of 1955 concerning Economic Crime (Wet Economic Delichten). However, the Criminal Code has not explicitly regulated the responsibility of corporations as perpetrators of criminal acts. ${ }^{2}$

The spirit of eradicating criminal acts of corruption after reform was rolled out marked by the making of various statutory products as follows: ${ }^{3}$

- Decree of the MPR Number XI / MPR / 1998 concerning "The Administration of a Yang State Clean and Free of Corruption, Collusion and Nepotism ";

- Act No. 28 Of 1999 regarding "State Administration Clean and Free from Corruption, Collusion and Nepotism (KKN)";

- Act No. 31 Of 1999 concerning "Eradication of Corruption Crime", which amends and replaces the old Law (Act No. 3 Of 1971). Also Act No. 15 Of 2002 concerning the Crime of Money Laundering, Act No. 30 of 2002 concerning the Corruption Eradication Commission. And those in the planning are the Perpu for the Acceleration of Corruption Eradication and the Act on Witness Protection against criminals.

With the acceptance of a corporation as a legal subject in addition to a natural human legal subject (natuurlijke persoon), the study of this matter becomes increasingly interesting because of the crimes committed by corporations. In this journal the author discusses how the Corporate Criminal Liability system, and the obstacles in imposing crimes against corporations.

\section{Research methods}

The purpose of writing this journal is to analyze theories of criminal responsibility and corporate criminal liability systems, in order to find out when the corporation is the responsible maker and manager. The approach method used is the statute approach (statutory approach) and the case approach (case approach), the method of analysis with qualitative analysis by interpreting data using library research.

\section{Results and Discussion}

\subsection{Concept of Corporate Criminal Liability}

The concept of criminal law regarding corporate responsibility has developed. Models of corporate accountability over time, namely:

\footnotetext{
${ }^{2}$ Warih Anjari, Pertanggungjawaban Korporas i Sebagai Pelaku Tindak Pidana, Jurnal Ilmiah Widya Yustisia, Volume 1 Nomor 2, November 2016. p. 120

${ }^{3}$ Arief. Barda Nawawi. (2003). Kapita Selekta Hukum Pidana. Bandung: PT Citra Aditya Bakti. p. 65-66
} 
- Legal Fiction Theory

Legal entities or corporations are an abstraction, not a concrete thing, so it is impossible to become a legal subject from a legal relationship. Legal Entity is a fiction that is something that doesn't actually exist but people turn it on in the shadows for explain something. People behave as if there are other legal subjects, but their non-real form cannot perform actions so that those who impose it are humans as their representatives. ${ }^{4}$

- Ultra Virez Doctrine

A corporation is not entitled to take actions that are outside the objectives outlined in its articles of association, so that such actions are null and void and cannot be enforced by shareholders.

- Identification Theory (Alter Ego Theory)

The will power of the corporation's manager represented the will power of the corporation. In this case the corporation can only be held accountable for individual actions acting on behalf of the corporation and that person has a high position or key function in the corporate decision-making structure. ${ }^{5}$ In this concept, the perpetrators of natural crimes (humans) are identified first. If the perpetrator is a person acting for the corporation (directing mind), then the corporation can be held accountable.

- Strict Liability

Absolute accountability regardless of the inner attitude or mens rea of the doer. This accountability model is the most practical accountability.

- Vicorious Liability (Respondent Superoir)

Someone, in this case the corporation, can be held accountable for the actions of other people or a substitute liability. This concept is based on the relationship between the employer and the worker, in which the employer is accountable for the actions of his workers within the scope of his duties and jobs.

- Sucsessive Liabilty

Criminal liability can be transferred to another person.

- Delegation Theory

Is a modification of identification theory, where the corporation is very large and the decision making is fragmented. The subject of the perpetrator of the criminal act that is accounted for is expanded, as long as that person exercises the authority of the corporation. ${ }^{6}$

To simplify the identification of corporate liability, Steven Box categorizes the scope of corporate crime, namely:

- Crimes for corporation, is a violation of the law committed by a corporation in an effort to achieve corporate goals to gain profit;

- Criminal corporation, which is a corporation that has the sole purpose of committing crimes;

\footnotetext{
${ }^{4}$ Ali, Chaidir. (1999). Badan Hukum. Bandung: Alumni. p. 32

${ }^{5}$ Muladi dan Diah Sulistyani. (2015). Pertanggungjawaban Pidana Korporasi (Corporate Criminal Responsibilty). Bandung: PT Alumni, Edisi Kedua Cetakan Pertama. p. 17

${ }^{6}$ Hamzah, Andi. (2008). Asas-Asas Huk um Pidana . Jakarta: Rineka Cipta. p. 41.
} 
- Crime against corporations, namely crimes against corporations such as theft or embezzlement of corporate property, in which case the victim is a corporation. ${ }^{7}$

Meanwhile, the types of Corporate Crime, according to Joseph F. Sheley, include:

- Defrauding the stock holders: a company that does not actually report the profits earned by the company to shareholders,

- Defrauding the public: tricking the public about the products produced;

- Defrauding the goverment: making untrue tax reports;

- Endangering employees: companies that pay less attention to the safety of their workers;

- Illegal intervention in the political process: collude with political parties by giving campaign contributions;

- Endangering the public welfare: the production process that gives rise to pollution. 8

\subsection{Corporate Criminal Liability System}

\subsubsection{Corporations as makers and also responsible}

In this accountability system there has been a shift in view, that corporations can be accounted for as makers, besides natural humans (natuurlijke persoon). So the rejection of corporate punishment based on the doctrine of the non-potest delinquere university, has undergone a change by accepting the concept of functional actors (functioneel daderschap). ${ }^{9}$ In the concept of law enforcement, the idea of balance should be prioritized with high integrity.

So in this system of accountability is the beginning responsibility directly from the corporation. As for the things that can be used as justification that the corporation as the maker and at the same time is responsible is as follows: First, because in various economic and fiscal crimes, the profits obtained by the corporation or the losses suffered by the community can be so large that it will not be balanced. if the punishment is imposed only on the management. Second, by only criminalizing the management, there is no guarantee that the corporation will not repeat the crime again. By punishing a corporation with the type and weight according to the nature of the corporation, it is hoped that the corporation can comply with the relevant regulations. $^{10}$

In Indonesia the initiating laws and regulations The placement of corporations as subjects of criminal acts and directly accountable is Act No. 7 Drt Of 1955 concerning Investigation, Prosecution and Economic Crime Trial, especially in Article 5 paragraph (1) which reads: "If an economic crime is committed by or on behalf of a legal entity, a company, an association of other people or a foundation., then criminal charges are filed and criminal penalties and disciplinary actions are imposed both against the legal

\footnotetext{
${ }^{7}$ Muladi dan Diah, Op. Cit., hlm, 19

${ }^{8}$ Singgih. (2005). Kejahatan Korporasi Yang Mengerik an. Tangerang: Pus at Studi Hukum Bisnis UPH. p.17

${ }^{9}$ Setiyono, H. (2003). Kejahatan Korporas i Analis is Viktimologi dan Pertanggungjawaban Korporas i, Dalam Hukum Pidana, Edis i kedua Cetakan Pertama. Malang: Banyumedia Publishing. P. 16

${ }^{10}$ Ibid., p.15
} 
entity, company, association or foundation, either against those who gave the order to commit the economic crime or who acted as a leader in the act or negligence or against both -both".

The next development was the birth of various rules Other laws outside the Criminal Code, which regulate the same thing, for example Article 39 of Act No. 3 of 1989 concerning Telecommunications, Article 24 Act No. 2 of 1992 concerning Insurance Business, Article 20 of Act No. 311999 concerning Corruption Crime, and others.

In connection with the acceptance of corporations as perpetrators of criminal acts and being accountable, then speaking of corporate criminal liability there are several doctrines regarding corporate criminal responsibility, including:

- Identification Doctrine;

According to this doctrine, criminal responsibility, the principle of "mens rea" is not ruled out, where according to this doctrine the mental actions or attitudes of senior corporate officials who have a "directing mind" can be considered as corporate attitudes. This means that the mental attitude is identified as a corporation, and thus the corporation can be directly accountable. ${ }^{11}$ The director's action or will is an act and corporate will. ${ }^{12}$

This accountability differs from vicarious liability and strict liability, where in this identification doctrine, the principle of "mens rea" is not ruled out, whereas in the doctrine of vicarious liability and the doctrine of strict liability, the principle of "mens rea" is not required. or the principle of "mens rea" does not apply absolutely. ${ }^{13}$

- The doctrine of vicarious liability; Substitute liability is the responsibility of a person without personal fault, taking responsibility for the actions of others. ${ }^{14}$

- The Doctrine of Strict Statutory Accountability Law (strict liability).

The principle of absolute responsibility without having to prove the existence or absence of an element of error on the perpetrator of the crime. This criminal liability is known as strict liability crimes. ${ }^{15}$

\section{When the Corporation Commits a Crime}

Talking about this according to Barda Nawawi Arief, ${ }^{16}$ In the special rules of criminal law scattered outside the KHUP, which recognize corporations as subjects of criminal law, there is no uniformity in their regulations, meaning that some formulate and some do not.

Specific provisions governing when a corporation commits a criminal act, for example Act No. 7 of 1955. This is regulated in Article 15 paragraph (2) which reads: "An economic crime is also committed by a person, on behalf of a legal entity, a company,

\footnotetext{
11 Muladi. (2004). Penerapan Pertanggungjawaban Korporasi Dalam Hukum Pidana. Semarang: Fakultas Hukum Undip. p. 21.

12 Hanafi. (1999). Reformasi Sistem Pertanggungjawaban Pidana, Jurnal Hukum Volume 6 Nomor 1. P. 17

13 Priyatno, Dwidja. (1991). Pertanggungjawaban Korporasi Dalam Hukum Pidana. Bandung: Sekolah Tinggi Hukum. P. 93-94

14 Ibid., p. 53

${ }^{15}$ Atmasasmita, Romli. (1996). Perbandingan Hukum Pidana. Cetakan I. Bandung: Mandar Maju. P. 76.

${ }^{16}$ Arief, Barda Nawawi.Op. Cit., 2003, p. 230.
} 
an association of people, or a foundation, if the action is committed by people either on the basis of an employment or other relationship, acting within the environment of a legal entity, company, association or foundation regardless of whether the individual committed the economic crime separately or for them together there are elements of the said crime ".

In connection with the aforementioned formulation, Barda Nawawi Arief said: In the formulation of Article 15 paragraph (2) Economic Crime, there is a formulation that "seems" to explain when a legal entity is said to have committed a criminal act. The formulation reads "a criminal act is also committed by or on behalf of a legal entity and so on ". Given the words "also done" it is clear that the above formulation is only a fiction which expands the form of a criminal act which is not actually committed by a legal entity but is "considered" to have been committed by a legal entity. So the above formulation does not explain the definition of when a legal entity is said to have committed (as the maker) of a criminal act. ${ }^{17}$

In the elucidation of Article 15 UUTPE (Act No. 7 Drt / 1955) which, among others, reads: "Paragraph 2 determines in which cases an economic crime is deemed to have been committed by a legal entity. ${ }^{18}$ After seeing the formulation of Article 15 paragraph (2) and the explanation it turns out that has not provided confirmation regarding the limits or measures used to determine that an economic crime is committed by a legal entity or corporation. It's just that it says the limit or size is mentioned, namely:

- based on a work relationship or other relationship; and

- acting within a legal entity environment.

So a criminal act of corruption is deemed to have been committed by a corporation if the criminal act is committed by people:

- based on a work relationship or other relationship;

- acting in a corporate environment;

- either alone or collectively. ${ }^{19}$

\section{Criminal Liability Against Value-Based Corporations Justice}

Seeing the current reality where corporations are increasingly playing an important role in people's lives, especially in the economic field, so that the doctrine of the nonpotest delinquere university (legal entities cannot commit criminal acts) has changed with the acceptance of the concept of functional actors according to Rolling. ${ }^{20}$ Based on the foregoing, namely that the corporation is the subject of a criminal act, then This raises problems regarding their accountability in criminal law. Because it is related to criminal responsibility, so far in Indonesia, it adheres to the principle of error. This means that being convicted of a person is not enough if that person has committed an act that is against the law and is against the law, but in the perpetrator there must be

\footnotetext{
17 Muladi, Barda Nawawi Arief. (1992). Teori-teori dan kebijakan pidana. Edisi Revisi. Bandung: Alumni. P. 134.

${ }^{18}$ Priyatno, Dwidja. Op. Cit., p. 174.

${ }^{19}$ Arief, Barda Nawawi. Op. Cit., p. 209.

20 Atmasasmita, Romli. (1996). Perbandingan Hukum Pidana. Cetakan I. Bandung: Mandar Maju. p. 8
} 
an element of guilt, or what is known as the principle of no crime without error (Geen straf zonder schuld; keine strafe ohne schuld).

This principle is not listed in the Indonesian Criminal Code or in regulations other, however, the application of this principle is now unquestionable, because it would be contrary to the sense of justice if a person was convicted even though he was completely innocent. Since the main principle of criminal responsibility is error, new problems arise with the acceptance of corporations as subjects of criminal law.

Mistakes can be intentional or negligent. With the acceptance of a corporation as a subject of criminal law, problems arise regarding corporate criminal responsibility in criminal law, namely whether a legal entity (corporation) can have mistakes, whether in the form of intentional or negligent.

Whereas it is said that an act is criminal if it fulfills the following elements: the act is criminal (there are already regulations prohibiting it), the existence of an offense (criminal responsibility) and the purpose of the crime (the purpose of giving punishment / sanction).

As it is known that criminal law is a system, so that there is a relationship between the general provisions of the Criminal Code, with the specific provisions both in the Criminal Code and those scattered outside the KUHP.

In explaining the conspiracy of evil, the author emphasizes the General Rules of Book I of the Criminal Code, based on the provisions of Article 103 of the Criminal Code, so only Chapters I to Chapter VIII apply to all special provisions both in the Criminal Code (Book II and Book III), as well as those spread outside the Criminal Code.

As it is known that the provisions regarding the consensus are deep KUHP is regulated in Book I Chapter IX. This means that the provisions regarding the conspiracy do not apply to special provisions scattered in outside of the Criminal Code, for example in Act No. 31 of 1999 in conjunction with Act No. 20 of 2001. Therefore, the UUPTPK must regulate it separately.

Article 2 paragraph (2) UUPTPK regulates criminal weighting, namely With the threat of death penalty, this type of punishment cannot be imposed on the corporation, as regards the explanation of Article 2 paragraph (2), it is stated that one of the reasons for the weighting of the crime is if there is a repetition of the criminal act of corruption but there is no provision when it is said that the repetition occurs, and in Article 20 paragraph (7) the principal criminal sanctions that can be imposed on the corporation are formulated, which have the same consequences as the single criminal formulation because there is no other alternative if the principal punishment (fine) is not paid by the corporation.

In the elucidation of Article 2 paragraph (1), Act No. 31 Of 1999, explained that: what is meant by "unlawfully" in this Article includes acts against the law in both formal and material terms. Namely, even though the act is not regulated in statutory regulations, if the act is considered despicable because it is not in accordance with the sense of justice or the norms of social life in society, then the act can be punished.

An action in general can lose its character as against the law not only based on provisions in legislation but also based on principles of justice or legal principles that are not written and are general in nature. The element of an unlawful nature can be removed based on the principles of justice and unwritten legal principles if by action: 
- The state is not harmed;

- Public interest served; and

- The defendant himself did not get a profit.

The non-punishment of the corporation as a criminal act is followed by Tangerang District Court Decision Number 30 / Pid.B / 1990 / PN / TNG dated 1 August 1990 regarding the poisoned biscuits, where the convicted person was the director of $\mathrm{CV}$ Gabisco, both as a person and in his capacity as Director. Meanwhile, the Decision of the Supreme Court of the Republic of Indonesia Number 2239K / Pid.Sus / 2012 regarding the case of tax evasion of PT. Asian Agri Group (AAG). A corporation is sentenced to a crime even though the prosecutor does not prosecute the corporation. In both decisions, the perpetrators of the criminal act are given priority to humans, not yet touching.

\section{Closing}

The concept of criminal liability by corporations is increasingly experiencing the times. The accountability system referred to is Strict Liability, Vicorious Liability, Successive Liability, Identification Theory, and Delegation Theory. The corporate liability system as a criminal offender follows the general criminal law liability system, which is based on error. In imposing crimes against corporations are: Application of an accountability system that is individual, direct, and based on schuld (conventional criminal liability system); Proof of corporate wrongdoing is very difficult; There is no regulation on corporations as the subject of criminal acts in both material criminal law and formal criminal law.

Taking into account the aforementioned weaknesses, whether it is the weakening of the penal code (criminal liability) of the corporation, as well as the general weaknesses that affect the penalties (criminal responsibility) regulations of corporations in the UUPTPK, the suggestions that can be given are: UUPTPK needs to be amended.

\section{References}

\section{Journals:}

[1] Hanafi. (1999). Reformasi Sistem Pertanggungjawaban Pidana, Jurnal Hukum Volume 6 Nomor 1.

[2] Warih Anjari, Pertanggungjawaban Korporasi Sebagai Pelaku Tindak Pidana. Jurnal Ilmiah Widya Yustisia, Volume 1 Nomor 2, November 2016

\section{Books:}

[1] Arief. Barda Nawawi. (2003). Kapita Selekta Hukum Pidana. Bandung: PT Citra Aditya Bakti.

[2] Arief. Barda Nawawi. (2014). Masalah Penegakan Hukum dan Kebijakan Hukum

[3] Pidana dalam Penanggulangan Kejahatan. Jakarta: Kencana. Ali, Chaidir. (1999). Badan Hukum. Bandung: Alumni.

[4] Priyatno, Dwidja. (1991). Pertanggungjawaban Korporasi Dalam Hukum Pidana. Bandung: Sekolah Tinggi Hukum.

[5] Loqman, Loebby. (1993). Delik Politik Di Indonesia. IND-HILL-CO. 
[6] Muladi, (2004). Penerapan Pertanggungjawaban Korporasi Dalam Hukum Pidana. Semarang: Fakultas Hukum Undip.

[7] Muladi and Diah Sulistyani. (2015). Pertanggungjawaban Pidana Korporasi (Corporate Criminal Responsibilty). Bandung: PT Alumni, Edisi Kedua Cetakan Pertama.

[8] Muladi, Barda Nawawi Arief. (1992). Teori-teori dan kebijakan pidana. Edisi Revisi. Bandung: Alumni.

[9] Atmasasmita, Romli. (1996). Perbandingan Hukum Pidana. Cetakan I. Bandung: Mandar Maju.

[10] Setiyono. (2003). Kejahatan Korporasi Analisis Viktimologi dan Pertanggungjawaban Korporasi, Dalam Hukum Pidana. Edisi kedua Cetakan Pertama. Malang: Banyumedia Publishing.

\section{Regulations:}

[1] Act No. 20 of 2001 concerning Amendments to Act No. 31 of 1999 concerning Eradication of Corruption Crimes.

[2] Act No. 28 of 1999 concerning State Administration Clean and Free From Corruption, Collusion and Nepotism (KKN)

[3] Emergency Act No. 7 Of 1955 concerning Investigation, Prosecution and Economic Crime Court

\section{Internet:}

[1] www.pnmedanko ta. go. id /ma in/inde x.p hp/te nta ng-pe ngad ila $\mathrm{n} / \mathrm{p}$ ro fil-

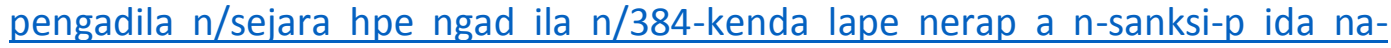
terhadap-korporasi-sebaga ipe lak u-tindak-p ida na-korupsi-putusan3.ma hka ma ha gung. go. id 